\title{
The Implementation of Hadith Studies for Visually Impaired People in Malaysia: Issues and Challenges
}

\author{
Norhafizah Ahmad $^{1 *}$, Wan Ainaa Mardhiah Wan Zahari ${ }^{1}$, Arwansyah Kirin ${ }^{1}$
}

${ }^{1}$ Department of Islamic Studies, Centre for General Studies and Co-curricular, Universiti Tun Hussein Onn Malaysia, 86400 Parit Raja, Batu Pahat, Johor, MALAYSIA

*Corresponding Author

DOI: https://doi.org/10.30880/jstard.2020.02.03.013

Received 30 September 2020; Accepted 30 November 2020; Available online 31 December 2020

\begin{abstract}
Hadith is the second source in Islam after Quran. The role of hadith is very important in Islam especially in explaining and justifying the contents of Quran. The study of hadith for visually impaired people is very important and necessary in the special education system. There are some challenges that need to be considered in preserving the study of hadith for visually impaired people. These challenges must be faced together in order to create an equality of hadith educational opportunities toward visually impaired people regardless of their shortcomings. However, the exposures of hadith study occur only on a small scale while hadith also plays an important role in Muslim daily life. Therefore, the main objective of this article is to explain the issues and challenges faced by visually impaired people in implementing hadith studies. The qualitative approach is used in this research by using document analysis method from books, articles, journals, internet etc. The early finding shows that the hadith study for visually impaired people in Malaysia facing great issues and challenges. These challenges exist in several aspects including the lack of instructional resources, the weakness of educational institutions and the lack of teaching aid. Hence, this research is able to identify the issues and challenges faced by visually impaired people to pursuit hadith and guiding them to learn and love the Prophet SAW and his Sunnah.
\end{abstract}

Keywords: Implementation, hadith studies, visually impaired people, issues and challenges

\section{Introduction}

The study of hadith for the visually impaired people is very significant and necessary in the special education system even though it have a big challenge. In order to preserve the study of hadith for the visually impaired people, there are several challenges that need to be faced and considered. These challenges must be faced together in order to create equal opportunities for hadith education for all Muslims regardless of their shortcomings.

\section{The History of the Development of the Study of Hadith Braille}

The history of growth and development of hadith studies among the visually impaired people is very limited in its information. Most visually impaired religious studies classes focus on the Braille Quran study. Meanwhile, the formal hadith study in Malaysia only focus on normal people. In terms of teaching aid, there is no formal hadith study class for the visually impaired people until now [1]. In fact, according to Zakaria [2], there is only one module available for the visually impaired people, namely 'Hadith of the End Times'. The study of hadith for the visually impaired people is only done on a small scale and is limited to a small number of groups only. For example, the study of hadith is taught to visually impaired students who study at Darul Quran, JAKIM. In addition, the study of this hadith may be followed by a small number of groups if they attend lectures in the mosque by listening way only [3].

The development of the hadith study for the visually impaired people is not in line with the development of Quran Braille because the text of Quran Braille has been introduced in Malaysia since the early 50s. According to Zakaria [3], 
there is only one book of hadith in Braille form entitled 'Hadith of the End Times'. This is the effort of Mr. Hj. Muhammad Lee Abdullah who is one of the visually impaired people who is currently serving in PERTIS. He is one of the visually impaired people who helped a lot in the effort of publishing Islamic reading materials in Braille until now. The book has been successfully brailing in the 90 s. It is a book of hadith written by al-Banjari, a religious teacher in a madrasah in Kedah. In this book, there are 40 hadiths about the end of time that only the material is in Arabic and written in Arabic Braille [3]. Besides, there is a development in the effort to publish hadith material in Braille when there is a visually impaired individual who is trying to translate Kitab of Mukhtasar Sahih Bukhari in collaboration with Yayasan Sofa [4].

In 2017, a book of hadith was published by UKM Press in Braille writing which is Hadith 40 Imam Nawawi. The book by Dr. Ahmad Yunus Mohd Nor is a transcript of the original Hadith 40 manuscript without making any changes except a few modifications in writing to suit the needs of the visually impaired people. The production of this book is a pioneer for the improvement of teaching aids for special education programs, especially in the study of hadith. This is a positive development in the effort to preserve the hadith study among the visually impaired people. These books will be used as a source of reference for the hadith study for the visually impaired people [5].

\section{Methodology}

This study used a qualitative method. Document analysis technique is used to gather information related to the study of hadith for visually impaired people in Malaysia. Among the materials referenced for this article are thesis, journals, articles, books, the internet etc. All these materials are analysed according to the perspective of the visually impaired people and the field of hadith. Apart from conducting document analysis, a semi-structured interview was also conducted with two representatives from the Association of the Visually Impaired Muslims of Malaysia (PERTIS) who are responsible for conducting religious programs, da'wah activities and publications for visually impaired people in Malaysia. The use of interview technique also helps in the collection of information, views and knowledge on the study of hadith among the visually impaired people which supports the results of the study obtained.

\section{The Issues and Challenges}

The education system in Malaysia is undergoing a transformation that requires a teacher's commitment. Reforms in the education system are seen as opportunities to optimize individual development. Challenges in the teaching profession today need sacrifices especially in educating a disabled person. The challenges that exist in the hadith study for the visually impaired people consist of several aspects: a) the lack of instructional resources, b) the weakness of educational institutions and c) the lack of teaching aids.

\subsection{The Lack of Instructional Resources}

The profession as a teacher is a very noble job in the sight of Allah SWT, especially an educator to the people with special needs. The role of the instructional resources has a profound impact on each of their students. Some challenges must be faced by the instructional resources in educating the visually impaired people to know the hadith of Rasulullah SAW such as the mastery of knowledge and charity in preparation for the visually impaired people, personal challenges including mental and physical and teaching skills that different from the normal class.

\subsubsection{Mastery of Knowledge and Charity}

Mastery of knowledge and charity is an important aspect of education. It is one of the conditions in shaping the personality of the instructional resource especially in the education aspect. This is in line with the Quran's call for the importance of knowledge as Allah SWT said in Surah al-Isra' 17:36.

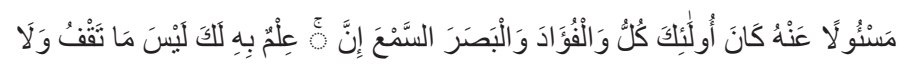

Meaning:

And pursue not that of which you have no knowledge; for every act of hearing, or of seeing or of (feeling in) the heart will be enquired into (on the Day of Reckoning) [6].

Although issues related to science are seen as a common and simple phenomenon, the debate is complex and very broad. This is because the differences in knowledge according to the Islamic and Western perspectives find us with various issues and the most significant is from the true source of a knowledge that separates between knowledge and religion. This separation resulted in confusion in the Western world known as the dark age. Knowledge from an Islamic perspective does not reject the approach put forward by Western theory. Imam Hasan al-Banna stressed that Islam liberates the mind, encourages the observation or study of the universe, elevates the position of knowledge and scholars as well as welcomes something good and beneficial as long as it adheres to the Qur'an and sunnah. Therefore, the most effective remedy for the sustainability of this knowledge is the concept of charity [7]. 
In the context of mastery of knowledge and charity, teachers need to strengthen themselves with a variety of knowledge and apply it in all actions. Among the knowledge that should be available to a teacher of the visually impaired people is religious knowledge, parenting, education (special education), doctorate (pediatrician, ophthalmologist, ear specialist and so on), therapy (Quran and remembrance, how to work and communication) etc [7]. However, a study by Norakyairee et al. [8] found that teachers who are just beginning to teach the visually impaired people do not master the Braille code of the Quran and do not have basis for reading Braille writing. While mastering Braille writing is very important for a special education educator with vision problems. Even in the study of hadith, teachers should master Arabic Braille writing because most sources of hadith are in Arabic. This issue occurs because some teachers participate in this field as a 'diving midwife'. The issue of teachers who are not proficient in the Quran Braille code is seen to stem from the teacher training received before being placed on duty in a special school. This is because all teachers for Islamic Education in special education secondary schools only follow teacher training for Islamic Education and are not given exposure to the field of Special Education. This results in most teachers not having the skills to use Braille codes. They are also not exposed to the types of vision problems and how to deal with them causing teachers to try to learn these things themselves after being placed in Special Education secondary schools.

The big challenges facing by visually impaired instructional resource include the ability to identify the level of visually impaired people to facilitate the teaching and learning process. This identification process is important so that teachers can isolate the types of vision problems and apply different methods in the teaching and learning process for completely blind students and myopic students. Therefore, in helping the visually impaired people to master the reading of a material, various techniques are used such as the Braille code in textbooks for completely blind students. While teaching via computer and liquid crystal display (LCD) is used for students who suffer from severe myopia. By using this technique, students will interact with the computer through the reader screen or magnifying glass so that the writing is clearer and larger [9].

In addition, the need to master Braille writing is also necessary for the study of hadith because Braille is the only form of writing that can be understood by this group through print media or written reading material. The lack of instructors in mastering Braille writing will complicate teaching matters for the visually impaired people. This problem seems evident when normal people are not trying to master the Braille writing while the online multimedia tutorial, which is 'eKodbrailleBM' to teach Malay Braille code has been established to benefit normal people. The people who have to learn Braille are trainee teachers in special education, special education teachers who are teaching visually impaired people, parents with blind children and social workers who serve the blind [10]. The opportunity to learn and master this Braille writing should be taken by normal people, especially those who master the field of hadith so that the knowledge of hadith can be conveyed clearly to the visually impaired people.

Instructors should also equip themselves with various other knowledge such as knowing the methods used by the visually impaired people in learning a certain knowledge. For example, visually impaired students use Braille machines to write and read materials in Braille, including the Quran in Braille writing. Therefore, teachers who teach Islamic Education for visually impaired students need to have the skills to use Braille machines and read Braille writing, especially the Braille Quran [11].

\subsubsection{Personality and Self-Motivation}

According to the Islamic perspective, personality is closely related to human personality and noble morals. The development of human personality in the teachings of Islam demands emphasis from a spiritual and physical point of view. Imam al-Ghazali [12] sees personality development as encompassing all aspects of the individual self, which involves religious knowledge, faith, worship, appreciation of the Qur'an, manners of life, family life, earning a living, human relationships, morals and character as well as soul development and heart. In the context of education, the personality of the teacher affects the formation of the personality of the student, especially in terms of morality through the role model method. Sophisticated technology, complete teaching aids and robust pedagogy cannot replace the role of teachers as intermediaries of knowledge [7]. Thus, an excellent teacher personality will form a strong teaching personality and produce effective and consistent teaching. Among the personalities that need to be highlighted by the instructional resource in teaching the visually impaired people is interest and love of new challenges [13], patient with the greed of this group, respecting and paying attention to the needs of the visually impaired people[7].

In addition, self-motivation also plays an important role in visually impaired teachers. Instructors are a mirror of motivation for students in the process of educating their students to be successful human beings, even the role of teachers successfully overcomes the role of parents and peers [14]. The term motivation in Arabic is also known as targhib which means the awakening of individual inclinations and desires whether they like or want or give something they like [15]. Therefore, visually impaired teachers should have high motivation, do work just to get the pleasure of Allah SWT and understand the differences of each individual. Among the actions of teachers who have high selfmotivation in influencing the personality of the visually impaired people is to plan a more systematic classroom management system, diversify strategies, creativity and innovation in teaching and learning process, divide the visually impaired people into groups to ensure the learning process works effectively and conduct individual teaching as appropriate [7]. 
Awareness of educating the visually impaired people with the heart is very necessary because the heart is the basis for changes in human thinking and behavior. Its significant role in human life has caused the Qur'an to repeat the word heart (qalb) 132 times. In this context, the approach of educating with the heart has a loving connection born of noble parental feelings. Therefore, as teachers who are given the award to educate the visually impaired people , they must love and them as their relatives, advising and preventing from immorality, encouraging loving deeds, caring for, educating, educating, nurturing and nurturing the disabled vision [7]. Naturally, the process of teacher education and training should determine prospective teachers who have high interest, attitude and motivation towards the teaching career as well as high skills in terms of teaching and learning. In other words, motivation and skills are the criteria that need to be given due attention in training and courses regularly towards strengthening the quality of teachers in the field of Special Education.

\subsubsection{Teaching Skills}

Teaching skills are a basic element in the Malaysian Standard Teacher Model. There are three standards in empowering teacher professionalism, namely the practice of the values of teacher professionalism, knowledge and understanding as well as teaching and learning process skills. The term skills contain various meanings such as dexterity, efficiency, intelligence and wisdom, intelligence and expertise [15]. Skills require high ability and do not come to a person except through experience, constant self-testing and schooling.

In the context of special education, skills can generally be defined as competencies and knowledge of employment in technical fields involving cognitive, psychomotor operations and effective use of resources [7]. A study conducted by Mohd Mokhtar \& Aliza [11] found that teachers who teach in special education only 34.7\% who know teaching strategies for students with special needs and only $17.4 \%$ who have a professional qualification in the field of religion. Therefore, teachers need to learn to explore knowledge and update knowledge to be more advanced than their students either in the field of special education, religion or teaching skills for the visually impaired people. Visually impaired educators should also ensure that they are equipped with the skills of educating, nurturing, guiding, good teaching techniques and following the ability of the visually impaired people and the skills to use fuel effectively. Skills, competencies and knowledge in imparting skills to people with special needs are necessary to facilitate two-way communication between teachers and the visually impaired people, especially in the study of hadith.

In addition, teachers also need to have communication skills. In the context of education, educators need to communicate wisely with the visually impaired people in ensuring that the information delivery process is implemented successfully. On that basis, the Ministry of Education Malaysia has established the Special Education Campus Teacher Education Institute located in Cheras, Kuala Lumpur since 1962. This effort is done to produce competent and educator-minded teachers through a dynamic teacher development program towards the standard school education world [16]. This effort is also seen as a continuous training and learning process for visually impaired teachers. This shows that the role of teachers is very big when they are considered as teachers because their main task is to impart knowledge and educate students to become moral human beings. Teachers as instructors should plan teaching activities, appropriate teaching aids, implement teaching plans and make assessments to increase effectiveness and improvement in teaching.

\subsection{The Weakness of Educational System}

Educational institutions play an important role in the development of visually impaired studies in Malaysia. Improvements in educational system should be done without denying the equality rights in the aspect of education program, infrastructure and support system, so that the needs of the visually impaired people in Islamic studies, especially the study of hadith can be implemented successfully.

\subsubsection{Education Program}

The special education system for students with special needs in Malaysia has been arranged through special education programs. The Special Education Division has been established to operate this special education service. This program requires special techniques that suit the needs of students. There are special schools and special education programs established to house this students with special needs. In addition, different teaching and learning strategies and approaches are used according to the category of disability or problem encountered. These categories include learning disabilities, hearing problems and vision problems. As for vision problems, they are categorized according to their learning needs, namely students who are blind and visually impaired.

Among the strategies and focus of the Ministry of Education Malaysia to bridge the education gap is to strengthen the program for students with disabilities. The special education school program is fully administered by the Special Education Division. The division was developed to provide special education to Students with Special Needs for the Visually Impaired and Hearing. Programs provided include preschool education programs, primary education, secondary education and technical or vocational education. To follow all the programs, several conditions have been set, among them are 6 to 14 years old, certified by a medical practitioner and can take care of themselves without the help of others. Academic learning as well as facilities such as hostels, food and beverages are also provided for preschool 
and primary education programs. As for secondary education programs, technical and vocational streams are provided for students aged 13 to 19 years [17].

Several programs have been prepared by the Special Education Division for this students with special needs [7], among them are:

\section{a. Integration Special Education Program}

Integration Special Education Program is an educational program for students with special education needs who are only attended by students with special needs in special classes in government schools or government-aided schools. All students with special needs need to develop the talents and potential of students through vocational education to produce skilled people towards improving the quality of life. The potential students with special needs is placed inclusively in mainstream classes [18]. The program is fully administered by the State Education Department, while the Special Education Division is responsible for policy matters and their filling [17].

\section{b. Special Education Program Integration with Inclusive Approach}

This program is a special education student program that they will be placed with regular day school students in one class. They will follow all the subjects in the regular class like regular students. However, the list of student names will be maintained in the special class register. This program is also a program under the Special Education Division. There are two forms of inclusive education, namely semi-inclusive education and full-time inclusive education. Through semi-inclusive education, students only attend learning classes with day school students on certain subjects only. They will undergo special classes for the rest of the time. Meanwhile, in full-time inclusive education, special education students will follow all subjects in regular daily classes together like regular students [7].

\section{c. Special Rehabilitation Program}

This program is implemented by the Ministry of Education Malaysia to help students with 3M problems, namely reading, writing and counting. This program is established in every primary school. The focus towards eradicating the $3 \mathrm{M}$ problem is also enshrined in the Third Thrust: Empowering national schools and the Fourth Thrust: Bridging the education gap, in the Education Development Master Plan 2006-2010. Through these two cores, several action plans are planned to ensure students master the basics of 3M at Level 1. The Ministry of Education has strengthened the Special Rehabilitation Program by upgrading special rehabilitation classes and providing adequate trained rehabilitation teachers including in underserved schools [18].

\section{d. Special Education Preschool Education Program}

This flexible and informal educational program is conducted through the concept of 'Learning Through Play'. This program is specifically for students with special needs aged between four to six years. It aims to provide early exposure and form a readiness to go through the world of learning before going to the real world of school. For vision problems, several additional components are included in the program, in addition to some basic components modified from the National Preschool Curriculum, including orientation and modality, daily life skills, sensory training, low vision training, Braille skills and computer literacy [7].

\section{e. J-QAF Special Education Program}

This program was introduced to overcome the weakness of the level of mastery of the recitation of the Qur'an while enabling all Muslim students to finish the recitation of the Qur'an before moving to secondary school. The Special Education j-QAF program implemented is a program to strengthen Islamic Education in special education for students with special needs. Al-Quran education is implemented through the method of Iqra 'one to six, in addition to the study and learning of fardhu ain and practical in prayer. This program is implemented according to two categories of schools, namely the Special Education Program Integration of learning, vision and hearing problems as well as the School of Special Education [7].

A study by Hajarul Bahti et al. [19] found that teachers who teach Tilawah al-Quran lack the input of teaching techniques in the field. The initiative of the teachers themselves is needed so that they have the best skills in dealing with these visually impaired students. Therefore, improvements to the teacher training system need to be made to ensure that Islamic Education teachers who will teach in Special Education schools get early exposure on the students to be faced and appropriate teaching methods. Weaknesses in the aspect of teacher training will affect students and cause some students to be unable to master the skills of reading the Quran. This is due to the lack of emphasis on learning at the primary school level again. The study found that students from Sekolah Kebangsaan Pendidikan Khas (SKPK) Princess Elizabeth, Johor Bahru have better basic Quran reading skills than students from other primary schools. This is because the teachers at SKPK Princess Elizabeth have the skills to use the Braille Quran and effective teaching techniques that place more emphasis on the mastery of the Quran recitation of their students. Thus, the 
mastery of Quran recitation skills at the secondary level is a series of implementation of the teaching of Tilawah alQuran at the primary school level again. Weaknesses that occur in primary schools are brought to secondary schools which causes them to continue to be unable to master the skills of Recitation of the Quran well. Thus, the teaching system of Tilawah al-Quran at the primary school level needs to be improved to overcome these challenges [19].

In addition, the shortage of teaching time is also a constraint for the teaching process of students with special needs vision problems in schools. The teaching of the subject of Tilawah al-Quran for Islamic Education subjects at the upper secondary level by Islamic Education teachers are only allocated three hours only and one additional time for reinforcement. This little time is used to emphasize the components involved with the exam only. While the Quran reading skills are not focused because they are not tested in the national examination system. Therefore, the addition of time to improve the reading and skills of the Quran for visually impaired students should be given attention to improve their mastery of skills in Tilawah al-Quran. This time constraint also requires teachers to teach students on a 'one to one' basis, so more teachers and the reduction of learning groups are necessary to improve the reading proficiency of students with visual impairment and current constraint issues [19]. Tilawah Al-Quran's teaching system for students with special needs unsatisfactory vision problems as well as time constraints in teaching becomes a measure of the weakness of educational institutions for the visually impaired people. Therefore, the challenge of studying hadith will also be faced and will suffer the same fate as the teaching of the Quran Braille if hadith is made one of the additional subjects for students with special needs vision problems in schools.

Besides that, the use of language also has an impact on the learning and teaching of hadith. Language is an intermediary or medium used to communicate with each other. Since the Qur'an was revealed in Arabic, mastery in Arabic is necessary to understand the Qur'an. Mastery of the Arabic language is also the basis of understanding and appreciation of the Qur'an and hadith. Thus, the need to learn Arabic can no longer be denied, especially from the religious context, which is to increase their understanding of religion. However, the practice of teaching and learning Arabic is still at an unsatisfactory level [20]. Most of the visually impaired people in Malaysia do not have an Arabic language background and cause them to feel far from the knowledge of hadith. They do not have the opportunity to learn Arabic, while Arabic is very important in the study of hadith [3]. No revelation from the beginning about hadith is also a factor in the lack of interest to continue to deepen the knowledge of hadith. Early exposure to knowledge is very important to create a sense of interest and determination to learn it. For example, learning Arabic through distance education. Zamri and Hakim [21] found that some students were indifferent to the modules provided and did not show seriousness in learning Arabic language skills courses at the Faculty of Islamic Studies, UKM. This is due to insufficient material and a lack of exposure to the use of Arabic dictionaries. This also happens to the visually impaired people and causes them to still be less clear with the real goals and importance of hadith studies. This was agreed by Suhaila et al. [22] found that among the factors of the public not learning Arabic is because there is no opportunity to learn, no time to learn, do not know it is important, no need to learn, less important than other languages and not interested in learning. The benefits of learning Arabic are enormous in the context of the study of the Qur'an and hadith. Although the issue of teaching Arabic has been discussed continuously by education experts in the specialization of Arabic, the challenges faced by those involved in planning to attract Arabic language lovers are not small. Various efforts are made to ensure the effective teaching of this language and bring as many benefits as possible, including training programs for teachers, expanding the teaching of this language to national secondary and primary schools, the production of suitable fuel and others [20]

\subsubsection{Infrastructure}

In general, among the issues and challenges that exist in the teaching of Special Education Program teachers in Special Education Schools, Malaysia is the need for infrastructure that supports learning and teaching of Islamic Education [23]. Infrastructure refers to facilities whether class, transportation or finance to facilitate the visually impaired people to deepen the knowledge of hadith. Studies have found that access to public services and facilities is still plaguing these groups which in turn restricts movement and prevents their integration into society [24]. Uncomfortable classroom conditions interfere with visually impaired people efforts to deepen their religious knowledge. Rumiza [25] found that the study respondents had problems to master the Braille Quran at an early stage due to the problem of uncomfortable classroom conditions while attending classes at the Malaysian Association for the Blind (MAB) Complex, Brickfield. Although the study classes held every Saturday and Sunday received encouraging responses from members of the Malaysian Association of the Visually Impaired (PERTIS), but almost all the students who study here complain that their place of study is less comfortable and needs to be given attention by PERTIS. This Quran study class was conducted in a place of prayer without complete equipment. Therefore, this problem needs to be addressed immediately so that students can attend the Quran study class comfortably and more enthusiastically. Among other suggestions is that PERTIS should provide a more comfortable place to study for students by providing equipment such as chairs, desks and others.

Although the issue of teaching Arabic has been discussed continuously by education experts in the specialization of Arabic, the challenges faced by those involved in planning to attract Arabic language lovers are not small. Various efforts are made to ensure the effective teaching of this language and bring as many benefits as possible, including 
training programs for teachers, expanding the teaching of this language to national secondary and primary schools, the production of suitable fuel and others [20].

Infrastructure in terms of transportation is also an obstacle for the visually impaired people to deepen their religious knowledge. Rumiza [25] also stated the problem of financial factors to commute to the place of study of the Quran. The increasing fares further add to their burden of commuting each week while attending Quran study classes. In addition, problems with public transport such as slow buses also make it difficult for the visually impaired people to move. The problem presented is expected to get the attention of the parties involved to find a solution. For students who attend classes in Kuala Terengganu also face almost the same problems, namely transportation problems and financial problems. Most students have trouble commuting to and from school because they live far away and have to change buses or taxis to get to class. Based on the interviews conducted many other students want and are interested in attending this Quran study class but can not come since the residence is far away and it is difficult to get suitable transportation.

Finance is also the most important resource in daily life and also the smooth running of an organization. Forward or backwards an organization depends on financial resources. Organizations that lack financial resources are an obstacle to carrying out various activities. Rumiza [25] stated that the problems faced by students in Kuala Terengganu are due to financial factors. Although PERTIS has provided a special fund to cover the cost of travel and transportation of students to come to the Quran class students stated that the money was slow to obtain and had to wait a long time to earn money and had to use their own money first to pay transportation fares each class held.

\subsubsection{Support System}

In order to develop educational institutions for the visually impaired, strong support from various parties is needed. This role is not a mere individual effort but a shared responsibility. Lack of support from certain parties will cause weaknesses in the educational institutions of the visually impaired people in Malaysia. Therefore, among the parties that can help in the formation of the education system for the visually impaired people are mosques, families, nongovernmental organizations (NGOs), government and private bodies.

The mosque as a center for da'wah activities should play an important role in implementing the da'wah agenda for both the normal and the disabled. The glorious history of Muslims has shown that Ummi Maktum, a visually impaired person benefits from the mosque as a field of worship, seeking knowledge, political affairs and many more. However, now the role of the mosque in the study of the Quran and hadith among the visually impaired people in Malaysia is still far behind compared to the role that has been played by other religious institutions such as the church. The history of education for the disabled in Malaysia has been pioneered by Christian missionaries and they are seen as far ahead in channeling contributions to their followers from the visually impaired [26]. The institution of the mosque through its pulpit channel every Friday should emphasize the importance of channeling aid to this group both in the form of finance and services. The institutions of the mosque should give awareness to the community and then restore its original function as it played in the time of the Prophet SAW.

Research on the role played by mosque institutions in providing space and study opportunities for the Quran among the visually impaired people did not find satisfactory results. Although there are efforts to hold al-Quran study classes at Masjid al-'Azim through the joint venture of the Malacca Islamic Religious Council and the Blind Society of Malaysia Melaka, the effort is still at the proposal stage. The main problem that is increasingly realized by all parties is to get Quran teachers who are skilled in Braille writing is difficult nowadays and researchers think this is also the fate that befell the study of the Quran in the Mosque al-'Azim [26]. This reality is a very sad thing as the mosque institution should be more advanced in dealing with such issues compared to other associations or government institutions. Naturally, mosques in Malaysia not only provide efficient infrastructures such as elevators, special routes, screens and others but also provide special hadith studies for the visually impaired people and other disabled.

In addition, the family also plays an important role in the life of the visually impaired people. Environmental elements including school management, peers and family roles also help students' academic achievement. A study by Rumiza [25] found that parents are the main driver for the visually impaired people to read the Quran. Therefore, parents need to provide strong support to visually impaired children in order to reduce the burden borne by the school in ensuring that all students can master the Quran reading skills well. In the context of the role of parents, the study found that some parents completely handed over teaching tasks to teachers at school without monitoring when at home during school holidays. This makes the task of Islamic Education teachers more difficult and the burden borne heavier, especially in the field of teaching the Quran. Accordingly, parents can set up a parent support group to assist the school in carrying out the planned activities [8]. In addition, this group can provide ideas and financial contributions towards increasing the level of mastery of their special children in a subject.

Support from normal friends is also needed to encourage the visually impaired people to learn the science of hadith. Friends are the motivators and helpers to read any information from the book. Friends also play an important role in studying the Qur'an. As many as 51.4 percent agreed and thought that friends helped them a lot when reading the Quran and improving the reading of the Quran. All respondents admitted that friends are the most important human beings who influence them to learn to read the Quran. The lack of reader services to read books or articles makes it difficult 
for the visually impaired people to deepen their knowledge. Studies also show that students with disabilities in the Institute of Public Higher Education (IPTA) rely heavily on the help and support of their close friends. Among the assistance provided to them includes transportation and sign language translation as this facility is not provided by the IPTA. Some facilities provided are not enough. Therefore, the IPTA must bear the responsibility to provide these facilities well. Although there are friends who do not understand and consider them as a burden especially when it comes to group work (Hasnah et. al. 2010: 26), the fact is that this perception should be changed in each individual. Selfishness and not thinking about the welfare of the visually impaired people should be discarded because Islam itself encourages every human being to help each other [27].

NGOs also play their role in spreading the mission of Rahmatan lil Alamin, by holding programs to increase the spirit and role of the visually impaired people in deepening hadith. However, the problem faced by various NGO organizations is that there is no coordination with each other, and cause programs to be made based on their respective goals. This is experienced by the visually impaired. The coordination of da'wah organizations related to the visually impaired people is becoming more complicated because there is no close communication relationship between da'wah organizations. The organization of visually impaired NGOs may be looking for missionary partners who can help them resolve coordination issues in various aspects. NGOs that do not have a clear plan are among the factors that are ineffective in preaching. This includes lack of information, no da'wah strategy, no da'wah manners and ethics, lack of effective communication techniques and not using influential da'wah media. As a result, da'wah becomes blurred, the target is to stay away from preachers and certain groups to belittle da'wah efforts. Ali Jarishah [28] said, there are some preachers make da'wah activities as the main source of income. Carrying out da'wah without sincerity but driven by the urge to live in luxury is a bad attitude of the preacher. Some preachers are not proactive in preaching, they are just waiting for a salary. The place and time provided for the preacher is often not filled because the preacher is busy doing work that can be done by others. The attitude of these preachers is detrimental to the future of da'wah itself. Therefore, this should be avoided in every preacher who holds the leadership of an NGO so that the role of NGOs can be fully utilized by the visually impaired people.

\subsection{The Lack of Teaching Aid}

Another challenge that hinders the process of studying hadith for the visually impaired people is teaching aids. The study found that Islamic Education teachers face the problem of lack of teaching aid in Tilawah al-Quran because most of the reference material in Braille is only available for other subjects. But for Islamic Education subjects especially Quranic texts and tajwid reference materials are not found in Braille. Only a limited number of Braille Quran manuscripts are used by students in this special education secondary school. This makes it difficult for visually impaired teachers and students to implement the teaching and learning process of Tilawah al-Quran in their very limited abilities. This requires the cooperation of all parties in the effort to increase the reference materials of Tilawah al-Quran and matters related to it using Braille code [19]. The lack of teaching aid for the visually impaired people not only involves the study of the Quran but also for the study of hadith. There is no suitable Braille reference for the visually impaired people [4]

According to studies, teaching aids play an important role in helping them master the recitation of the Quran [7]. Skills in using fuel that is appropriate to the situation, time, place and level of ability of students as well as interesting should also be emphasized by the instructional resource. Teachers need to choose methods that can arouse or stimulate students' interest so that they like the lesson and their memory of the things discussed can last a long time. With this suitability, R\&D will be more effective. Along with the development of current technology, Quranic learning methods are now assisted by various media such as print media, communication media, websites, and compact discs [29]. Thus the teaching of visually impaired students can also use these various media as support in a more effective learning process.

For an organization, resources finance is important for the success of an activity, not to mention the activities carried out using influential equipment such as the use of print media and electronic media that can not be used because it involves high costs. In fact, the lack of publication of hadith reading material in Braille is also due to financial factors because the cost of producing reading material in Braille is quite high compared to regular reading material. Therefore, these financial limitations must be overcome in ensuring that the teaching and learning process for the visually impaired people runs smoothly.

\section{Conclusion}

Exposure to the challenges in the teaching and learning process of the visually impaired people is necessary so that the instructional resource of this group has the opportunity to make careful preparations before starting the teaching process. In addition, educators should understand that the role and involvement of Islamic Education teachers in the field of special education is not only a complement to the existing curriculum group, but their role is very significant in the beautiful context of religious life. This is due to the challenges of Islamic Education and special education teachers who need extraordinary knowledge and skills to adapt these elements while interacting with these special students. 
For the visually impaired people, it turns out that this group faces various challenges in learning hadith either in terms of readiness of teachers, weaknesses in the education system and lack of fuel. Despite the limited access or resources to use to study hadith, but it is not an obstacle for this group in the effort to emulate the Prophet SAW. In fact, the existence of social media, radio, television, lectures, public talks, internet, blogs, religious education syllabus in schools and reading books by literate people has helped many people to learn hadith.

In addition, the study of hadith for the visually impaired people has enormous significance in the lives of this group. Among them is to meet the needs of the visually impaired people as a Muslim individual who has the right to deepen religious knowledge, especially the study of the Qur'an and hadith, as a guide to emulating the Prophet SAW in all aspects, develop the potential of the visually impaired people who are often underestimated by normal human beings and as an encouragement for this group always deepen knowledge despite having physical deficiencies. Therefore, it is time for the community to cultivate a caring attitude towards those who are unfortunate and no longer deny the rights and needs of this group.

\section{Acknowledgement}

The author would like to express their gratitude to Universiti Tun Hussein Onn Malaysia, for the assistance and the information provided to ensure the success of the study.

\section{References}

[1] Ahmad Yunus Mohd Noor and Tengku Intan Zarina Tengku Puji 2014 Keperluan hadis Braille dalam Pendidikan Khas: Satu Cabaran terhadap Pengajian Islam Seminar Warisan Nabawi (SWAN 2014) Peringkat Antarabangsa (Nilai: Institut Wasatiyyah Malaysia \& Fakulti Pengajian Quran Sunnah Universiti Sains Islam Malaysia) p 309

[2] Zakaria Yahya 2014 Al-Qur'an Braille Interview, 16 Ogos

[3] Zakaria Yahya 2015 Pengajian hadith bagi OKU penglihatan di Malaysia Interview, 6 Oktober

[4] Zamzuri Ghani. 2015 Pengajian hadith bagi OKU penglihatan di Malaysia Interview, 12 Oktober

[5] Ahmad Yunus Mohd Nor 2017 Hadis 40 Imam Nawawi Versi Braille Bangi: UKM Press p 1

[6] Abdullah Yusuf Ali 2005 The Holy Qur'an: Text and Translation (Kuala Lumpur: Islamic Book Trust) p 331

[7] Norhasnira Ibrahim, Norakyairee Mohd Raus, Nur Adzam Rasdi, Noornajihan Jaafar, Norazman Alias, Norullisza Khosim, Norzulaili Mohd Ghazali and Mat Fauzi Osman 2015 Pengajaran Al-Quran Braille (Bandar Baru Nilai: Penerbit Universiti Sains Islam Malaysia) p 42-49

[8] Norakyairee Mohd Raus, Mohd Nur Adzam Rasdi, Norazman Alias, Norhasnira Ibrahim, Norullisza Khosim, Noornajihan Jaafar, Ab. Halim Tamuri, Norshidah Mohamed Salleh and Hajarul Bahti Zakaria 2013 Pengajaran al-Quran Braille: Isu dan cabaran semasa International Journal on Quranic Research (IJQR) 3(4) 87

[9] Mohd Khairul Anuar Muhamad 2009 Teaching and Learning Methods of Islamic Education for The Blind Students: A Case Study at Sekolah Kebangsaan Pendidikan Khas (SKPK) Princess Elizabeth, Johor Bahru (Nilai: Universiti Sains Islam Malaysia) p 52

[10] Lee Lay Wah and Lee Bee Hiang 2010 Analisis jenis kesalahan kod Braille Bahasa Melayu dalam kalangan pelajar yang mengambil kursus bermasalah penglihatan (Penang: Pusat Pengajian Ilmu Pendidikan) p 4

[11] Mohd Mokhtar Tahar and Aliza Alias 2004 Isu pengajaran dan pembelajaran pendidikan Islam pelajar berkeperluan khas Wacana Pendidikan Islam Siri ke-3 (Bangi: Fakulti Pendidikan, Universiti Kebangsaan Malaysia) p 395-406

[12] al-Ghazali, Abu Hamid Muhammad 1939 Ihya' cUlum al-Din (Mesir: Matbacah Mustafa al-Bab al-Halabi)

[13] K.A. Razhiyah 2010 Anak Istimewa (Bentong: PTS Publications \& Distributors Sdn. Bhd)

[14] Abdullah Hassan and Ainon Mohd 2011 Guru Sebagai Pendorong Dalam Darjah (Selangor: PTS Profesional Publishing Sdn. Bhd)

[15] al-Ba'labaki, Ruhi 2003 Al-Mawrid: Qamus cArabiy-Injiliziy (Bayrut: Dar al-cIlm li al-Malayin)

[16] Portal Rasmi IPG Kampus Ilmu Khas 2015 Visi dan misi http://www.ipik.edu.my [5 Disember 2015]

[17] Hasnah Toran et al. n.d. Kertas Polisi: Dasar Pendidikan Kanak-Kanak Berkeperluan Khas Malaysia (Bangi: Universiti Kebangsaan Malaysia)

[18] Portal Rasmi Bahagian Pendidikan Khas 2014 http://www.moe.gov.my/bpkhas [27 Ogos 2014]

[19] Hajarul Bahti Zakaria, Mohd Huzairi Awang @ Husain, Bani Hidayat Mohd Shafie, Nor Hayati Fatmi Talib and Nabiroh Kassim 2010 Isu dan cabaran guru dalam pendidikan al-Quran pelajar bermasalah penglihatan Prosiding Persidangan Antarabangsa Pendidikan Guru ke-4 p 751-762

[20] Rahimi Md. Saad, Zawawi Ismail and Wan Nordin Wan Abdullah 2005 Pengajaran dan pembelajaran bahasa Arab berasaskan web $\mathrm{p} 1$

[21] Zamri Ariffin and Hakim Zainal 2000 Pengajaran dan pembelajaran kursus Bahasa Arab menerusi jarak jauh di FPI Kertas kerja Seminar Kebangsaan Pengajian Jarak Jauh: Kecemerlangan Pengajian Jarak Jauh Dalam Alaf Baru (Bangi: Universiti Kebangsaan Malaysia) p 48 
[22] Suhaila Zailani @ Hj Ahmad, Ummu Hani Hj. Hashim, Salamiah Ab. Ghani, Khazri Osman, Zainuddin Ismail \& Hakim Zainal 2012 Modul pengajaran dan pembelajaran Bahasa Arab menerusi al-Quran untuk orang awam di Malaysia Prosiding Kongres Pengajaran Dan Pembelajaran Universiti Kebangsaan Malaysia p 11

[23] Mohd Hanafi Mohd Yasin, Norani Mohd Salleh, Hasnah Toran and Mohd Mokhtar Tahar 2009 Infrastruktur bilik darjah program integrasi pendidikan khas menyokong pengajaran dan pembelajaran pendidikan Islam Wacana Pendidikan Islam Siri ke-7 (Peringkat Nusantara) (Gontor: Institusi Studi Islam Darussalam) p 540-546

[24] Lau Poh Li, Ahmad Shamsuri Muhamad and Chew Fong Peng 2011 Peranan kaunselor dan perkhidmatan kaunseling kerjaya bagi Orang Kurang Upaya Atikan Universiti Malaya 1(2) 233-246

[25] Rumiza Abdul Rahman 2010 Pengajian al-Quran dalam kalangan ahli Persatuan Orang-orang Cacat Penglihatan Islam Malaysia (PERTIS), di Kuala Lumpur dan Kuala Terengganu. Disertasi Sarjana Usuluddin Universiti Malaya p 66-80

[26] Mustaffa Abdullah 2010 Pengajian al-Qur'an dalam kalangan warga cacat penglihatan di Malaysia Jurnal AlBayan 8(1) 21-34

[27] Hasnah Toran, Mohd Hanafi Mohd Yasin, Mohd Mokhtar Tahar and Norasuzaini Sujak 2010 Sokongan dan halangan yang dihadapi pelajar-pelajar kurang upaya di sebuah Institusi Pengajian Tinggi di Malaysia Asean Journal of Teaching and Learning in Higher Education 1 (2)18-29

[28] Ali Jarishah 1986 Al-Ijtihat al-Fikriyah al-Mucasirah (Qahirah: Dar al-Wafa') p 283

[29] Norasikin Fabil, Zawawi Ismail, Zarina Shukur, Siti Fadzillah Mat Noor and Khairuddin Omar 2003 Teknologi Multimedia: Satu Inovasi pendekatan "Talaqqi dan Musyafahah" Wacana Pendidikan Islam Siri ke-3 (Bangi: Fakulti Pendidikan, Universiti Kebangsaan Malaysia) p 298-315 